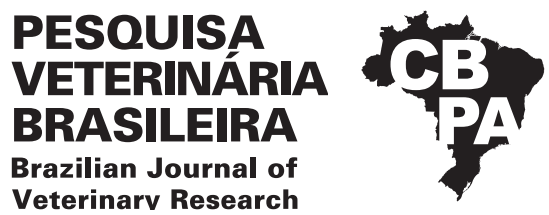

\title{
Cobalt deficiency in cattle and its impact on production ${ }^{1}$
}

\author{
Westerlly J. Silva² (D), Carolina C. Guizelini ${ }^{3}$ (D), Gumercindo L. Franco ${ }^{3}$ (D), \\ Rayane C.P. $\operatorname{Veiga}^{3}$ (D), Williane G. Arruda ${ }^{3}$, Valter A. Nascimento ${ }^{4}$, \\ Elaine S.P. Melo ${ }^{4}$ and Ricardo A. A. Lemos ${ }^{3 *}$ (D)
}

\begin{abstract}
Silva W.J., Guizelini C.C., Franco G.L., Veiga R.C.P., Arruda W.G., Nascimento V.A., Melo E.S.P. \& Lemos R.A.A. 2020. Cobalt deficiency in cattle and its impact on production. Pesquisa Veterinária Brasileira 40(11):837-841. Laboratório de Anatomia Patológica, Faculdade de Medicina Veterinária e Zootecnia, Universidade Federal de Mato Grosso do Sul, Avenida Senador Filinto Muller 2443, Vila Ipiranga, Campo Grande, MS 79074-460, Brazil. E-mail: ricardo.lemos@ufms.br

Two outbreaks of cobalt deficiency in beef cattle were diagnosed in Midwestern Brazil. We discuss the clinical, epidemiological, pathological features, therapeutic measures, and impact aspects of the production system associated with these outbreaks occurring outbreaks in two farms of extensive cattle raising-system in the state of Mato Grosso do Sul. Seven affected cattle were euthanized and necropsied. Tissues for histopathology and microelements dosage were secured. At Farm A, 3100 cattle of all ages got sick, and 396 died; at Farm B, 148 were affected, and 110 died. In both farms, cattle were fed the same mineral supplement. The main clinical signs were weight loss and weakness, even though a good supply of forage was available in the paddocks. Many cattle stop grazing and chew at tree barks, wood chips from fence posts, and bones. In addition to the deaths, there was a compromised growth, and the reproductive rates fell sharply. The necropsied cattle were thin, with rough hair coat and pale mucous membranes. The liver was diffusely orange and showed a lobular pattern. The bone marrow was gelatinous and diffusely yellow. Histological changes included hemosiderosis in the liver and spleen, hepatocellular vacuolar degeneration, and myeloid and erythroid hypoplasia of the bone marrow. In the white matter of four cattle's brains, the myelin sheath was markedly distended (spongy degeneration). Proliferative parasitic abomasitis was observed in three cattle. The presumptive diagnosis was based on the association of the clinical picture, the necropsy findings, and the ruling out of other possible causes. The diagnosis was confirmed by the favorable response to treatment with cobalt and vitamin B12 orally and by mineral supplementation.
\end{abstract}

INDEX TERMS: Cattle diseases, deficiency diseases, mineral deficiencies, cobalt.

RESUMO. - [Deficiência de cobalto em bovinos e seu impacto na produção.] Dois surtos de deficiência de cobalto em bovinos de corte foram diagnosticados. Os aspectos clínicos, epidemiológicos, anatomopatológicos, terapêuticos e impactos

\footnotetext{
${ }^{1}$ Received on August 10, 2020.

Accepted for publication on August 24, 2020.

${ }^{2}$ Graduate Program in Animal Science, Faculdade de Medicina Veterinária e Zootecnia (FAMEZ), Universidade Federal de Mato Grosso do Sul (UFMS), Av. Senador Filinto Muller 2443, Vila Ipiranga, Campo Grande, MS 79074-460, Brazil.

${ }^{3}$ Laboratório de Anatomia Patológica, Faculdade de Medicina Veterinária e Zootecnia (FAMEZ), Universidade Federal de Mato Grosso do Sul (UFMS), Av. Senador Filinto Muller 2443, Vila Ipiranga, Campo Grande, MS 79074460, Brazil. *Corresponding author: ricardo.lemos@ufms.br

${ }^{4}$ Faculdade de Medicina (FAMED), Cidade Universitária s/n Unidade 9, Campo Grande, MS 79070-900, Brazil.
}

no sistema de produção são descritos e discutidos. Os surtos ocorreram em duas fazendas de criação extensiva estado de Mato Grosso do Sul, Centro-Oeste brasileiro. Sete bovinos afetados foram eutanasiados e necropsiados. Na necropsia foram colhidas amostras para exames histopatológicos e dosagem de microelementos. Na Fazenda A, 3100 bovinos de todas as idades adoeceram e 396 morreram e na Fazenda B, 148 bovinos adoeceram e 110 morreram. Ambas as fazendas utilizavam o mesmo suplemento mineral. Os principais sinais clínicos observados foram emagrecimento e fraqueza, apesar da boa oferta de forragem nos piquetes, muitos bovinos deixaram de pastejar e comiam cascas de árvores, madeira das porteiras e ossos. Além das mortes, tiveram crescimento comprometido e os índices reprodutivos tiveram queda acentuada. Os bovinos necropsiados estavam magros, com os pelos arrepiados e 
mucosas pálidas. O fígado estava difusamente alaranjado e com evidenciação do padrão lobular. A medula óssea estava de consistência gelatinosa e difusamente amarelada. Alterações histológicas incluíam degeneração vacuolar hemossiderose que era moderada no fígado e marcada no baço. Hipoplasia mieloide e eritoide era vista na medula óssea. Na substância branca do encéfalo de quatro bovinos, a bainha de mielina estava marcadamente distendida (degeneração esponjosa). Abomasite parasitária proliferativa foi observada em três bovinos. 0 diagnóstico presuntivo baseou-se na associação do quadro clínico, nos achados de necropsia e na eliminação de outras possíveis causas. 0 diagnóstico foi confirmado pela resposta favorável ao tratamento com cobalto e vitamina B12 por via oral, e a suplementação mineral.

TERMOS DE INDEXAÇÃO: Doença de bovinos, doenças carenciais, deficiências minerais, cobalto, bovinos.

\section{INTRODUCTION}

Mineral elements are essential for animal nutrition, and their needs should be met through feeding practices, as the body cannot synthesize them. In balanced concentrations, they assist in the acid-base balance, forming structural components, such as enzymatic cofactors, and the transfer of energy (Riet-Correa 2007, NRBC 2016).

In farm animals, deficiency of mineral elements is due mainly to diets lacking the minimum requirements. Mild deficiencies lead to low fertility problems and low meat production, while severe forms can cause death (Tokarnia et al. 2000). Cobalt (Co) is an important microelement to ruminants' diet, as it is used by ruminal microorganisms for the synthesis of vitamin B12. In mammals, there are two vitamin B12-dependent enzymes: (1) methylmalonyl-CoA mutase, essential for the conversion of propionate to succinate, since it catalyzes the conversion of L-methylmalonyl-CoA into succinyl-CoA and (2) 5-methyltetrahydrofolate homocysteine-methyltransferase (methionine synthase), which catalyzes the transfer of methyl groups from 5-methyltetrahydrofolate to homocysteine, to form methionine and tetrahydrofolate. This reaction is crucial in recycling methionine after the transfer of its methyl group (NRBC 2016). The inability of ruminal microorganisms to convert succinate to propionate is the earliest manifestation of Co deficiency (Kennedy et al. 1991).

The first signs of Co deficiency are anorexia, moderate weight loss, and poor growth rates. When deficiency becomes severe, cattle exhibit rapid weight loss, fatty liver, and mucous pallor indicating anemia (NRBC 2016). The occurrence of outbreaks of Co deficiency only occurs in ruminants and most often affects animals held in pastures deficient in this microelement, which do not get a quality mineral supplement (Underwood \& Suttle 1999, Tokarnia et al. 2010). The recommended Co level for beef cattle is $0.15 \mathrm{mg} / \mathrm{kg}$ dry matter (DM) (NRBC 2016).

The goal of this study is to report two outbreaks of Co deficiency in beef cattle and discuss the clinical, epidemiological, pathological features, therapeutic measures, and impact aspects of the production system associated with these outbreaks.

\section{MATERIALS AND METHODS}

Our faculty team obtained the data on the outbreak during on-site visits to the two farms. We did three visits to each farm at 30-day intervals and constant interviews with the veterinarian practitioner tending the animal caretakers. Clinical examination was performed in Bovines 1, 3-7. The husbandry indexes were collected from the control sheets of each farm. In Farm A, groups of cattle were weighed to estimate weight loss. This property was monitored for a period of 12 months after our first visit to obtain reproductive data and calf weight at weaning. Bovines 1, 3-7 were euthanized due to their poor body, and health conditions. Bovine 2 was found dead. We necropsied these seven affected cattle, six of which (Bovines 1-6) were from Farm A, and one (Bovine 7) from Farm B. From the seven necropsied cattle, fragments were collected from all organs and fixed in $10 \%$ buffered formaldehyde, for subsequent routine histopathology. Liver fragments from Bovines 1-6 were also kept at $-20^{\circ} \mathrm{C}$ to determine the copper (Cu) and Co levels employing the optical emission spectrometry technique with inductively coupled plasma (ICP-OES). These results were compared with the reference values of $100 \mathrm{mg} / \mathrm{kg}$ for $\mathrm{Cu}$ and $>0.12 \mathrm{mg} / \mathrm{kg}$ for Co (Tokarnia et al. 2010).

Samples of the mineral supplement fed to cattle in both farms were analyzed for micro minerals in a laboratory accredited by the Brazilian "Ministério da Agricultura Pecuária e Abastecimento" (MAPA).

\section{RESULTS}

\section{Epidemiology and clinical signs}

Farm A, with extensive rearing of beef cattle, had sandy soil and a pasture predominantly composed of Brachiaria brizantha cv. Marandu. There grazed 8,327 cattle (of different ages, from calves to adults. Most of the cattle population were of Nelore (Bos indicus), although a small proportion of crossbreds (Bos Taurus $\mathrm{x}$ Bos indicus) existed. At the end of the outbreak, a total of 3100 cattle of all ages were sick, and 396 had died. Ten months before our first inspection of this farm on June 6,2019 , the owner had changed the suppliers of the mineral supplement; however, the new product supposedly contained adequate mineral levels similar to those used previously. There was no change in ad libitum supply practices, with daily estimates consumption of $120 \mathrm{~g}$ /bovine. In April 2019, cattle of various ages and categories began to show weight loss and weakness. Despite the good of plenty of grass pasture available, several cattle did not eat but chew on tree bark, wood chips from fence posts, and, occasionally, bones. Once affected cattle started to lose weight, they oud die within 30-60 days. In the terminal phase of cachexia, affected cattle were markedly apathetic and had difficulty standing up and moving around. They were easily pushed by other cattle, fell several times, and finally remained in decubitus until death. Deaths occurred in April (17.5\%), May (12\%), June (52.5\%) and July (18\%). In June, deaths occurred within a week after the completion of a new treatment protocol (detailed below) and ceased on July 11. Part of the deaths recorded in July may have occurred in the previous month, as only the carcasses were detected in July and not sick animals. Deaths by animal category were as follows: $52.5 \%$ heifers, $25.5 \%$ suckling calves, $9 \%$ yearlings, $7.5 \%$ weaned calves and $4.5 \%$ bulls.

On the date of the first inspection of Farm A, five hundred sick cattle of various categories had been treated with Co (10ml/bovine, intravenously [IV]) and dewormed with 1\% ivermectin containing vitamins $\mathrm{A}, \mathrm{D}$, and $\mathrm{E}(1 \mathrm{ml} / 50 \mathrm{~kg} / \mathrm{body}$ weight (bw), IV). There was no regression of clinical signs. We then recommended a new treatment protocol consisting of albendazole and cobalt sulfate (Valbazen 10 Cobalto $^{\circledR}, 30 \mathrm{ml}$ / cow, $20 \mathrm{ml} /$ heifer and $10 \mathrm{ml} /$ calves, orally) associated with 
vitamin B12, chloride cobalt, copper sulfate and iron citrate (Cobalzan ${ }^{\circledR}, 60 \mathrm{ml} /$ cow and $20 \mathrm{ml} /$ calf, orally) and medicine containing only vitamin B12 (Monovin B12 ${ }^{\circledR}, 5 \mathrm{ml} /$ cow and $2 \mathrm{ml} /$ calf, IV). The mineral mixture supplied to the cattle had been changed on June 3, 2019. A total of 3,040 cattle identified with clinical signs received the new therapy protocol. The treatment started on June 12, 2019, and was concluded on June 20,2019. Several cattle were feeble and, during handling, for medication, fell and were trampled by the others. Others lay down on the containment corral during medication and needed assistance to stand up and be removed from there. Some cattle were unable to walk to the corral and had to be treated in the pasture.

Surviving cattle showed a marked drop in weight gain, which was estimated by weighing 10 cows that weighed $300 \mathrm{~kg}$, compared to the normal average weight of $450 \mathrm{~kg}$. Ten suckling calves weighed an average of $115 \mathrm{~kg}$, while the expected weight for that age group would be $170 \mathrm{~kg}$ according to the farm records of previous years. Weaned calves also showed a marked reduction in weight gain. In 193 males and 192 females from Angus crosses ( $1 / 2$ Nellore $+1 / 2$ Angus), the mean weights ranged from 193 and $190 \mathrm{~kg}$, respectively. The normal weight would be over $220 \mathrm{~kg}$ for both sexes. Twentytwo Nelore males calves, and twenty females calves were weighed, and the respective average weights were $156 \mathrm{~kg}$ and $160 \mathrm{~kg}$. However, the expected weights were over $200 \mathrm{~kg}$. Ten healthy Nelore calves weighed $192 \mathrm{~kg}$.

The annual pregnancy rate, which previously to the outbark was $80 \%$, was reduced to $50.26 \%$, and the ratios of morbidity, mortality, and lethality were, respectively, 36\%, 4.75\%, and $13.2 \%$. In 2020, weaned calves' average weight was $237 \mathrm{~kg}$ for male Angus crosses, and 223.9kg for female Angus crosses. Nelore cattle weighed $220 \mathrm{~kg}$ (females) and $231 \mathrm{~kg}$ (males). The pregnancy coefficient in 2020 was $83.9 \%$.

In Farm B, the pasture also consisted mainly of Brachiaria brizantha cv. Marandu, and a total of 1,195 Nellore cattle of different categories. A hundred and forty-eight cattle of all categories got sick, of which 110 died. Eighteen months before the outbreak, cattle were offered, ad libitum, the same mineral supplement used lately in Farm A. Daily consumption was estimated at $100 \mathrm{~g}$ /bovine. Affected cattle lost weight and, despite the abundant pasture. They had difficulty defecating, and the feces were dry. Animals became extremely feeble and died within six months. When deaths started, the mineral supplement was changed and, although there were no new cases, thirty-eight bovines that showed severe signs did not recover and were treated with the same therapy protocol used property A. Despite the treatment, still two calves died. The rates of morbidity, mortality, and lethality in Farm B were $12.4 \%, 9.2 \%$, and $74.32 \%$. In addition to the deaths, calves had compromised growth, with weight deficits of up to $140 \mathrm{~kg}$ at weaning, when compared to the weights observed in the previous year. In the cows, there was a reduction from $80 \%$ to $60 \%$ in the pregnancy rate.

The levels of phosphorus $(0.25 \mathrm{~g} / \mathrm{kg})$, Co $(13.06 \mathrm{mg} / \mathrm{kg})$, iron $(981 \mathrm{mg} / \mathrm{kg})$ and sodium $(45.85 \mathrm{~g} / \mathrm{kg})$ in the mineral supplement used in both farms were well below those indicated by the manufacturer and $\mathrm{Cu}$, manganese and zinc were not quantified, as they were below the minimum detection range.

\section{Necropsy findings and histopathology}

The seven necropsied cattle were thin to cachectic, with rough and opaque hair coat; the ocular and oral mucosae were pale. Consistently, ruminal and intestinal contents were scant, liquid to slightly pasty, green with few bulky components, and occasional fragments of wood admixed with sand. The liver was diffusely orange, with evidence of the lobular pattern, and bone marrow was gelatinous and diffusely yellow.

Histological changes were similar in all necropsied cattle and included hepatocellular vacuolar degeneration and hemosiderosis that was moderate in the liver and marked in the spleen. Myeloid and erythroid hypoplasia was seen in the bone marrow. In the white matter of the brain of four cattle, the myelin sheath was markedly distended, forming a large clear space around the axon (spongy degeneration). The spongy degeneration was marked in the subcortical white matter of the frontal lobes, basal nuclei, midbrain, and medulla and moderate in the subcortical white matter of the parietal and occipital lobes, hippocampus, thalamus, cerebellum, and pons.

Three cattle had had to moderate proliferation abomasal glands associated with numerous nematodes (Trichostrongylus sp.). Nematodes were seen in the lumen of the glands and free in the lamina propria.

\section{Dosages of trace elements}

Levels of Co were low in the liver of two cattle $(0.06$ and $0.09 \mathrm{mg} / \mathrm{kg}$ ), and those of $\mathrm{Cu}$ were normal (from 190.99 to $380.24 \mathrm{mg} / \mathrm{kg}$ ).

\section{DISCUSSION}

The presumptive diagnosis of Co deficiency was made associating the clinical signs and epidemiological and by the elimination of other possible causes with similar clinical manifestations (Underwood \& Suttle 1999, Tokarnia et al. 2010, Constable et al. 2017). The diagnosis was confirmed by the positive response to treatment with Co and vitamin B12, orally, and mineral supplementation. The response to supplementation is the most conclusive means of determining whether a ruminant in production is affected by the deficiency of a trace element. The criteria to be evaluated are weight gain, milk production, and reproductive performance after introducing the treatment (Constable et al. 2017). Since we were dealing with a herd of beef cattle in this report, the response to weight gain and reproductive indices was evaluated. In both farms studied, cattle recovered weight gain. In Farm A, the reproductive indices were followed for a period of 12 months; after treatment, they returned to the indices recorded prior to the outbreak. The reproductive indices in Farm B, were not followed; however, the recovery in weight gain after the treatment was recorded.

The majority of deaths occurred in young cattle, which is a category considered more sensitive to Co deficiency (Tokarnia et al. 2010, Constable et al. 2017). However, despite the low mortality, breeding cows lost weight and were severely affected in their reproductive capacity. Low mortality with weight loss and reduced fertility is described in beef cows (Judson et al. 1997).

The clinical signs observed in cattle of Farms A and B are characteristic of Co deficiency (Tokarnia et al. 2000, Constable et al. 2017). In the outbreaks described here, weight loss and 
general weakness are attributing to the lack of food intake due to anorexia. Pica was a clinical sign seen in the first outbreak and has been described in association with Co deficiency in Brazil (Tokarnia et al. 2010, Riet-Correa 2007). However, no explanation is offered to why it develops.

The Co demands of cattle were not met by the mineral supplement and triggered the clinical condition described here. Co is essential in the diet of ruminants, as ruminal bacteria use it to synthesize cyanocobalamin (vitamin B12). It influences energy metabolism, facilitating the formation of glucose through methylmalonyl-CoA mutase, forming succinate from propionate (Underwood \& Suttle 1999, NRBC 2016). The clinical signs start when depletion of available Co reserves for the rumen microbiota occurs, blocking the production of vitamin B12 and resulting in the accumulation of propionate in the blood. Propionate activates receptors that control food intake (Underwood \& Suttle 1999). With low food intake, there is a further decrease in the ruminal microbiota, which also uses vitamin B12 for the conversion of succinate to propionate; consequently, there is a loss in the fermentation of forage consumed by Co deficient cattle, which causes a deficit in energy supply and, therefore, a marked loss of weight.

The necropsy and histopathological findings of necropsied cattle in the present outbreak are similar to previous reports of Co deficiency (Vellema et al. 1999, Tokarnia et al. 2000) as they are shared changes by severe malnutrition and anemia. The hypoplasia erythroid hypoplasia observed in the bone marrow indicates of anemia (Valli et al. 2016). It is known that low levels of vitamin B12 cause a reduction in the heme group's elements, resulting in anemia, a drop in the erythrocyte, hemoglobin, and hematocrit count (Stangl et al. 1999). The spongy degeneration in the white matter of the brain of four cattle has already been described in Co deficiency in sheep (Richards \& Harrison 1981, Constable et al. 2017) and was attributed to hepatic encephalopathy, since the liver, in that animal species, is the most affected organ. However, in cattle, it is not clear why this change occurs. One possible explanation is that, since Co is essential to trigger the chain of biochemical reactions necessary to glucose production, hypoglycemia leads to spongy degeneration (Suttle 1998, Barros 2016).

Two bovines presented Co levels below reference values $(0.5 \mathrm{mg} / \mathrm{kg}$ indicate a deficiency, values between 0.05 $0.12 \mathrm{mg} / \mathrm{kg}$ marginal deficiency and values above $0.12 \mathrm{mg} /$ $\mathrm{kg}$ are considered normal (Tokarnia et al. 2010). The Co levels of Bovines 2-4 and 5 were within normal reference levels. However, these four cattle were treated IV with Co by before blood sampling for analysis; possibly, this masked the results: after Co-administration, there is a rapid increase in the element in body tissues (Constable et al. 2017). Together with the failure responding to IV treatment, these results reinforce the importance of the administration of Co by the oral route. In severe cases, vitamin B12 should concomitantly be used parenterally. Several authors describe that the most efficient treatment is the oral supply of sources of Co at doses of $5-10 \mathrm{mg} / \mathrm{Co} /$ bovine/day (Tokarnia et al. 2010). The application of vitamin B12 is recommended because it has efficiency similar to that of the supply of Co. Its only disadvantage is being costly (Underwood \& Suttle 1999, Constable et al. 2017). The parenteral administration of Co is inefficient since it does not reach the rumen in a significant amount to be used by ruminal bacteria in the synthesis of vitamin B12 (Underwood \& Suttle 1999). Normal levels of Co in cattle treated by parenteral route indicate that the dosage of the element in the liver would not then be a good criterion for the diagnosis of Co deficiency. Cattle deficient in Co are more susceptible to gastrointestinal parasites. Thus, the administration of deworming drugs containing Co is indicated (Constable et al. 2017). Mineral supplementation with mixtures containing proper levels of $\mathrm{Co}$, although effective for preventing deficiency, is insufficient to reverse severe cases of the established disease, as demonstrated in this study.

Co deficiency must be distinguished from food deprivation, which is the most common cause of cattle wasting. Food deprivation is due mainly to a lack of planning for forage supply during the dry season when the amount and nutritional value of the forage mass decrease (Euclides Filho et al. 2002). In the outbreaks reported here, this was ruled out, since, in both farms, there was a good supply of quality forage. Although other mineral deficiencies, such as copper and phosphorus, can cause weight loss, they have distinct clinical characteristics. In copper deficiency, the most frequent clinical sign is acromotrichia, defined as hair discoloration, observed mainly around the eyes. In severe phosphorus deficiency, osteophagia is a characteristic clinical manifestation, and the occurrence of spontaneous fractures is frequent. Bovines can also have arched limbs, lordosis, narrow chest, small pelvis, and thin bones (Riet-Correa 2007). Although severe phosphorus deficiency as the cause of death in the present study can be ruled out, the possibility of marginal deficiency of this element cannot be completely discarded, as phosphorus was not properly represented in the mineral mix.

\section{CONCLUSION}

Cobalt deficiency occurs in the state of Mato Grosso do Sul, and the inadequate mineral supplementation of Co is a potential risk for the occurrence of outbreaks that cause losses of livestock business in the short and long term. Early recognition of this deficiency is essential for decision making in order to mitigate the losses.

Acknowledgements.- Two of the authors (R.A.A. Lemos and V.A. Nascimento) have research fellowships from the "Conselho Nacional de Desenvolvimento Científico e Tecnológico" (CNPq). This study was partially funded by the "Coordenação de Aperfeiçoamento de Pessoal de Nível Superior" (CAPES), Brazil, Finance Code 001, and by "Fundação de Apoio ao Desenvolvimento do Ensino, Ciência e Tecnologia do Estado de Mato Grosso do Sul” (FUNDECT).

Conflict of interest statement.- The authors have no competing interests.

\section{REFERENCES}

Barros C.S.L. 2016. Fígado, vias biliares e pâncreas exócrino, p.181-266. In: Santos R.L., Alessi A.C. (Eds), Patologia Veterinária. $2^{\mathfrak{a}}$ ed. Editora Roca, Rio de Janeiro.

Constable P.D., Hinchcliff K.W., Done S.H. \& Grünberg W. 2017. Nutritional deficiencies, p.817-822. In: Ibid. (Eds), Veterinary medicine: a textbook of the diseases of cattle, sheep, goats and horses. Vol.1. 11 ${ }^{\text {a }}$ ed. Elsevier, St Louis.

Euclides Filho K., Corrêa E.S. \& Euclides V.P.B. 2002. Boas práticas na produção de bovinos de corte. Embrapa Gado de Corte, Campo Grande, p.12-14. 
Judson G.J., McFarlane J.D., Mitsioulis A. \& Zviedrans P. 1997. Vitamin B12 responses to cobalt pellets in beef cows. Aust. Vet. J. 75(9):660-662. <https://dx.doi.org/10.1111/j.1751-0813.1997.tb15365.x><PMid:9325545>

Kennedy D.G., Young P.B., McCaugley W.J., Kennedy S. \& Blanchflower W.J. 1991. Rumen succinate production may ameliorate the effects of cobalt-vitamin B12 deficiency on methylmalonyl CoA mutase in sheep. J. Nutr. 121(8):12361242. <https://dx.doi.org/10.1093/jn/121.8.1236><PMid:1677683>

NRBC 2016. Nutrient Requirements of Beef Cattle. 8th ed. National Academies Press, Washington, D.C. 475 p.

Richards R.B. \& Harrison M.R. 1981. White liver disease in lambs. Aust. Vet. J., 57(12):565-568. <https://dx.doi.org/10.1111/j.1751-0813.1981. tb00437.x> <PMid:7340780>

Riet-Correa F. 2007. Doenças carenciais, p.223-257. In: Riet-Correa F., Schild A.L., Lemos R.A.A. \& Borges J.R.J. (Eds), Doenças de Ruminantes e Equídeos. Vol.2. 3a ed. Editora Pallotti, Santa Maria.

Stangl G.I., Schwarz F.J. \& Kirchgessner M. 1999. Cobalt deficiency effects on trace elements, hormones and enzymes involved in energy metabolism of cattle. Int. J. Vitam. Nutr. Res. 69(2):120-126. <https://dx.doi.org/10.1024/03009831.69.2.120><PMid:10218149>
Suttle N.F. 1988. The role of comparative pathology in the study of copper and cobalt deficiencies in ruminants. J. Comp. Pathol. 99(3):241-258 <https://dx.doi.org/10.1016/0021-9975(88)90048-5>

Tokarnia C.H., Döbereiner J. \& Peixoto P.V. 2000. Deficiências minerais em animais de fazenda, principalmente bovinos em regime de campo. Pesq. Vet. Bras. 20(3):127-138. <https://dx.doi.org/10.1590/S0100736X2000000300007>

Tokarnia C.H., Peixoto P.V., Barbosa J.D., Brito M.F. \& Döbereiner J. 2010. Principais deficiências de minerais, p.88-115. In: Ibid. (Eds), Deficiências Minerais em Animais de Produção. Editora Helianthus, Rio de Janeiro.

Underwood E.J. \& Suttle N.F. 1999. Cobalt, p.251-274. In: Ibid. (Eds), The Mineral Nutrition of Livestock. 3rd ed. CABI, New York.

Valli V.E.O., Kiupel M. \& Bienzle D. 2016, Hematopoietic System. p.103-269. In: Maxie M.G. (Ed.), Jubb, Kennedy, and Palmer's Pathology of Domestic Animals. Vol.3. 6th ed. Elsevier Saunders, Philadelphia.

Vellema P., van den Ingh T.S.G.A.M \& Wouda W. 1999. Pathological changes in cobalto-supplemented and nonsupplemented twin lambs in relation to blood concentrations of methylmalonic acid and homocysteine. Vet. Q. 21(3):93-98. <https://dx.doi.org/10.1080/01652176.1999.9695001> <PMid:10427634> 